\title{
THE WATER SPRINGS - SOURCES FOR WATER SUPPLY AND IRRIGATION IN THE NISTRU RIVER BASIN
}

\author{
Maria Sandu ${ }^{a^{*}}$, Anatol Tarita ${ }^{\mathrm{a}}$, Raisa Lozan ${ }^{\mathrm{a}}$, Viorica Gladchic ${ }^{\mathrm{c}}$ Gheorghe Duca ${ }^{\mathrm{b}}$, \\ Sergiu Turcan ${ }^{\mathrm{a}}$, Elena Mosanu ${ }^{\mathrm{a}}$, Afanasie Prepelita ${ }^{\mathrm{d}}$ \\ ${ }^{a}$ Institute of Ecology and Geography, 1, Academiei str., Chisinau MD-2028, Republic of Moldova \\ ${ }^{b}$ Academy of Science of Moldova, 1, Stefan cel Mare Blvd., Chisinau MD-2001, Republic of Moldova \\ ' State University of Moldova, 60, Mateevici str., Chisinau MD-2009, Republic of Moldova \\ ${ }^{d}$ Hydro-Geological Expedition of Moldova, Republic of Moldova \\ *e-mail: sandu_mr@yahoo.com, phone: (+373 22) 73 15 50; 721774
}

\section{In Memory of Valeriu Ropot for his scientific contributions in Waters Protection}

\begin{abstract}
The present study estimates chemical composition and status of the groundwater from the Nistru (Dniester) river basin (about 360 springs and fountains). Research includes defining of springs/fountains location, evaluating physicochemical features of water, highlighting of main pollutants and pollution sources, establishing of water type and quality. It was established that springs/fountains with water that meets the criteria for drinking scope constitute $21 \%$, sanitary acceptable for consumption is water from 129 springs/fountains, with high content of dissolved salts (mineralization $>1000 \mathrm{mg} / \mathrm{dm}^{3}$ ) and hardness exceeding $10 \mathrm{me} / \mathrm{dm}^{3}$ (very hard water) were in $18.5 \%$ of sources and approximately $25 \%$ of the springs are water polluted with nitrates and its content is more than the MAC from 1 to 6 times.
\end{abstract}

Keywords: groundwater, chemicals state, pollution sources, correlation of components, water type and qualification.

\section{Introduction}

The groundwater plays special role in terrestrial water balance $[1,2]$. It is an important component of the hydrological cycle as part of the underground water flow being the largest reservoir of freshwaters, representing more than $97 \%$ of all water available for consumption in the world. EU Framework Directive on Water, adopted in 2000 , sets out the concrete objectives for groundwater related issues and namely: achieving good status (quantitative and chemical) and limiting its deterioration, "preventing or limiting" the discharge of pollutants, taking measures to reduce any significant and sustained tendencies of pollutant concentrations increase [3]. Additional conditions for chemical state and its assessment procedures, protection of groundwater against pollution and deterioration, including criteria for assessing good chemical composition are developed within Groundwater EU Directive 118/2006/EC [4].

Approximately $40 \%$ of the rural population is supplied with water from underground layers with hydrostatic pressure (6200 wells) and the first layer water (without pressure) (about 150 thousand wells and springs), which provides 1.811 million $\mathrm{m}^{3}$ /day confirmed reservations [5]. From the total national administered groundwater volume only $50 \%$ can be used for drinking purposes without prior treatment.

The change of composition and physical and chemical properties of groundwater are caused by human activity. The spectrum of natural and artificial pollutants is broad (nitrogen compounds, pesticides, selenium, sulphates, etc.), the mineralization and total hardness values of groundwater is exceeding with 2-5 and more times sanitary-hygienic norms and provokes nitrate pollution [6]. Variation of $\mathrm{NO}_{3}{ }^{-}$content and of borehole depth is an argument for groundwater pollution by nitrates that occurs vertically from the earth's surface. In the wells up to $30-40 \mathrm{~m}$ are registered the highest values of nitrate $[7,8]$.

In Moldova, the majority of small localities haven't the centralized water supply systems. The main legal act is the Law on drinking water [9], which regulates relations in the field of drinking water supply, aspects related to water for human consumption and provisions related to non-centralized water supply systems - installation and construction (wells, springs, etc.) for potable water capture and distribution without the supply to place of consumption.

The groundwater's quality depends on the surface water status. In the areas where the ground water basis is very permeable (sand, gravel), the connection between surface water and groundwater is strong [10]. But researches show that in the Republic of Moldova inland surface waters have a high degree of pollution [11-13], as pollutants in surface waters penetrate the ground and vice versa.

A comprehensive study on the quality, type and qualification of spring's water in the country were conducted for Prut Basin (about 400 springs) [14-17]. The evaluated correlation between nitrate content and the macro components of water in several wells and springs in the country highlights the potential pollutants and their accumulation trends [18]. About 160 wells and springs from all over the country were described by Overcenco A. and co-authors [19].

In the present study was estimated chemical state of groundwater from the Nistru river basin (about 360 springs and fountains in villages and communes of the administrative districts: Rezina, Soldanesti, Telenesti, Orhei, Calarasi, 
Straseni, Criuleni, Anenii Noi, Ialoveni, Causeni and Stefan Voda). Some results are published in the scientific editions [20-25]. Research includes the estimating of location in space of springs/fountains, evaluating physic-chemical features of water, highlighting pollutants and main pollution sources, establishing of water type and qualification for use.

The research was achieved within the State Program "Scientific research and water quality management" (coordinator acad. Gheorghe Duca), the project "Role of tributaries on the Nistru river water quality formation and study of springs water quality from the Nistru basin as sources for water supply and irrigation", leader Gladchi V.

\section{Research methods}

The research methods have been adopted in relation to the objectives of the study. Investigations on water sources included the following:

- Sampling. Water samples from springs/fountains (the Nistru river basin) were collected in accordance with regulatory requirements [26] in the type of dishware, storage conditions and performing analysis. In place of sample collection was determined smell, taste, flow, $\mathrm{pH}$ and water temperature.

- Assessment of chemical composition. Springs water content of components was determined in the laboratory by standard methods EN ISO [27, 28] and traditional $[29,30]$.

- Determination of water type and qualifier for consumption. It was evaluated water type and calculated the Stebler coefficients of irrigation [31] for researched waters. Water qualifier for consumption was established according to the provisions of the Governmental Decision of the Republic of Moldova [32].

- Correlation between water components. To assess the correlative links between ion concentrations was used to rank correlation index $r$ of Spearmen [33]. Spearman's rank correlation coefficient, like the Pearson $r$, measures the strength of relationship between two variables. While the Pearson product moment correlation coefficient requires both variables to be measured on an interval or ratio scale, the Spearman's rank correlation coefficient only requires data that are at least ordinal. When it is low of 0.05 , i.e. $\mathrm{R}<0.05$ means lack of correlation between the concentration of ions. The correlation coefficient from empirical regression curve [34] range from very small $(<0.1)$ to low $(0.1 \leftrightarrow 0.3)$, medium $(0.3 \leftrightarrow 0.5)$, high $(0.5 \leftrightarrow 0.7)$ to the very large, nearly perfect $(0.7 \leftrightarrow 0.9$ and $>0.9)$.

\section{Results and discussions}

According to the hydro geological characteristics in area of study, the groundwater's that feed springs/fountains are stored mainly in packages of Neogene aged rocks. The erosion processes that occurred along time, opened aquifers stratum and their water come up in the slopes of river valleys, large ravines and valleys. Over the level of rocks base erosion are spread the sub layer of rocks from inferior and medium Sarmatian. In these layers are concentrated the aquifers with stable exchange potential for spring's formation. Lower Sarmatian aquifer which has the greatest importance in the regional water supply is largely spread. The waters are concentrated in the limestone formations of shale cracked inclusions, sandstone and sand. Their thickness is ranging from 20 to 30 up to $50 \mathrm{~m}$. The discharge of the springs/fountains is from 0.05 to $1.0 \mathrm{~m}^{3} / \mathrm{s}$, but sometimes some of the water record exceeds the norm with more than $10 \mathrm{~m}^{3} / \mathrm{s}$. The salts content parameters of the waters are sweet, with a degree of mineralization below $1.0 \mathrm{~g} / \mathrm{dm}^{3}$ and occasionally $-1.5 \mathrm{~g} / \mathrm{dm}^{3}$ and after ionic composition they are magnesium-sodium hydrocarbonate type that go to west in the hydrocarbonate-sulphate and sulphate - hydrocarbonate.

Medium Sarmatian aquifer is sporadic widespread, being stuck in loamy and limestone rocks, which is spread over the inferior Sarmatian formation. This aquifer has a lower capacity due to lack of border between the two aquifers in these latitudes a stable layer of impermeable rock, so the waters flow downward, thus is fuelling inferior Sarmatian aquifer and increasing its flow. The flows of the springs/fountains that form from this aquifer varies considerably from 0.01 to $1.5 \mathrm{~m}^{3} / \mathrm{s}$ for those that flow from sandy loam rocks and from 10 or more liter for the ones flowing from limestone. The water are sweet, those of hydrocarbonate type with a fixed residue between 0.4 and $0.5 \mathrm{~g} / \mathrm{dm}^{3}$ [35].

Feeding area of aquifers practically overlaps with the limits of the target region. The presence of limestone karsts on the surface of river valleys facilitates penetration of atmospheric precipitation, which is the dominant source of supply, the same stands for the supply of the inferior Sarmatian aquifer from rivers. The Nistru river and its tributaries serve as main zone for water download, forming the hydrographical network of the territory [36].

The ionic composition occurs due to the relationship between ions accumulation in water and salts sedimentation corresponding to their solubility under the influence of physical-geographical, chemical and biological factors, but the peculiarities of water formation lead to a variety of ionic content and total mineralization. Thus the chemical composition of groundwater is not constant and supports changes both in the time and in the same aquifer values. Substances content in water increases as a result of evaporation and dissolving, the phenomenon that occurs mainly in groundwater horizons and intensifies as the temperature is increasing but the humidity decreasing, also as a result of horizontal and vertical migration, including from surface waters.

In this study, conducted during the period of 2009-2012 was determined geographical location, smell, taste, flow, $\mathrm{pH}$ and temperature (at sample collection), evaluated in laboratory conditions chemical composition of water from 362 springs/fountains from rural localities (about 160) of the Nistru river basin (villages and communes from 
the administrative districts Rezina, Soldanesti, Telenesti, Orhei, Calarasi, Straseni, Criuleni, Anenii Noi, Ialoveni, Causeni and Stefan Voda) to identify springs/fountains, water that is contaminated with various compounds in quantities exceeding the maximum allowable concentration (MAC).

The research results denote that water from all sources is colourless, has no specific odour and taste. District average values of hardness, mineralization, nitrates and macro components content in springs/fountains water from the Nistru river basin are presented in table 1.

District average values of hardness, mineralization, nitrates and macro components content

Table 1. in springs/fountains water from the Nistru river basin.

\begin{tabular}{|c|c|c|c|c|c|c|c|c|c|c|c|}
\hline $\begin{array}{l}\text { Average values of } \\
\text { physical-chemical } \\
\text { indexes }\end{array}$ & 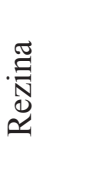 & 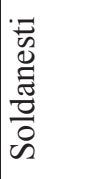 & 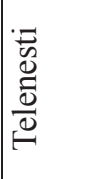 & 离 & 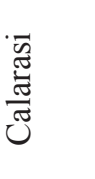 & 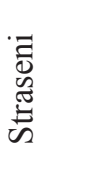 & : & $\begin{array}{l}\frac{1}{0} \\
\frac{0}{0} \\
\frac{\pi}{2}\end{array}$ & 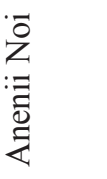 & 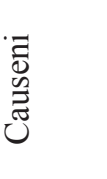 & 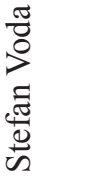 \\
\hline Hardness, me/dm ${ }^{3}$ & 10.1 & 7 & 10.9 & 9.5 & 9.6 & 10.4 & 9.8 & 11.4 & 10.6 & 9.96 & 12.9 \\
\hline $\mathrm{Ca}^{2+}, \mathrm{mg} / \mathrm{dm}^{3}$ & 123 & 84 & 134 & 114 & 92 & 104 & 82 & 107 & 145 & 84 & 44 \\
\hline $\mathrm{Mg}^{2+}, \mathrm{mg} / \mathrm{dm}^{3}$ & 49 & 35 & 54 & 48 & 63 & 65 & 68 & 78 & 43 & 71 & 129 \\
\hline $\mathrm{Na}^{+}, \mathrm{mg} / \mathrm{dm}^{3}$ & 60 & 95 & 211 & 91 & 116 & 127 & 158 & 136 & 188 & 240 & 259 \\
\hline $\begin{array}{l}\text { Mineralization, } \mathrm{mg} / \\
\mathrm{dm}^{3}\end{array}$ & 723 & 636 & 1220 & 768 & 863 & 982 & 1042 & 968 & 1225 & 1008 & 1717 \\
\hline $\mathrm{Cl}^{-}, \mathrm{mg} / \mathrm{dm}^{3}$ & 47 & 42 & 76 & 56 & 80 & 120 & 73 & 85 & 78 & 126 & 239 \\
\hline $\mathrm{HCO}_{3}^{-}, \mathrm{mg} / \mathrm{dm}^{3}$ & 536 & 445 & 663 & 566 & 484 & 550 & 563 & 623 & 675 & 617 & 526 \\
\hline $\mathrm{SO}_{4}^{2-}, \mathrm{mg} / \mathrm{dm}^{3}$ & 101 & 76 & 354 & 134 & 219 & 218 & 256 & 193 & 271 & 220 & 407 \\
\hline $\mathrm{NO}_{3}^{-}, \mathrm{mg} / \mathrm{dm}^{3}$ & 40.8 & 46.4 & 31.8 & 38.4 & 32.4 & 23.1 & 42.0 & 55.2 & 54.8 & 52.2 & 28.6 \\
\hline
\end{tabular}

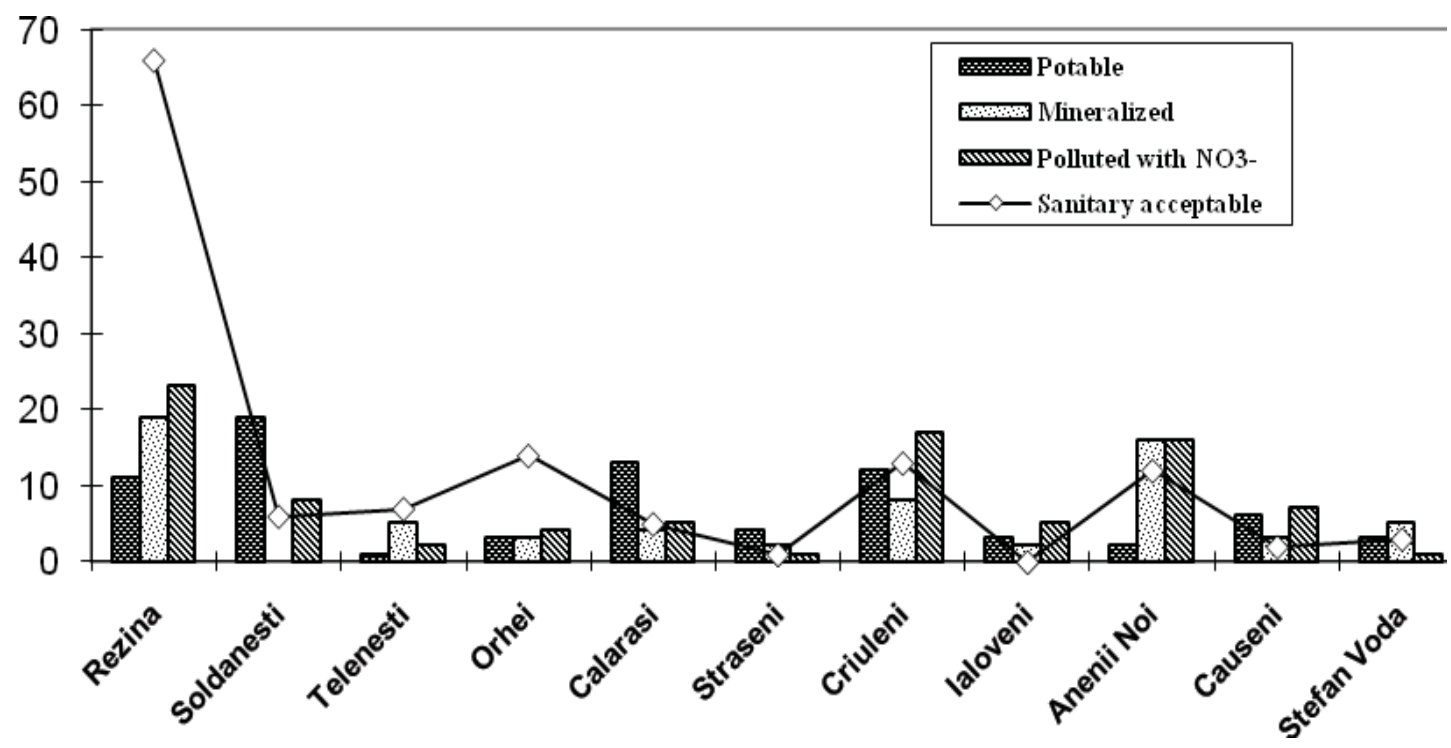

Figure 1. The qualifier of springs / fountains waters from under study localities in conformity with its chemical composition (“potable” - hardness $<7 \mathrm{me} / \mathrm{dm}^{3}$; “acceptable sanitary" - hardness 7-10 me/dm; “mineralized" - hardness $>10 \mathrm{me} / \mathrm{dm}^{3}$ and mineralization $>1000 \mathrm{mg} / \mathrm{dm}^{3}$ ).

Water springs from Stefan Voda and Ialoveni districts have the highest medium hardness, average of mineralization exceeding MAC - in villages and communes of the Stefan Voda, Anenii Noi and Telenesti districts and average nitrate content exceeding MAC - in villages and communes of the Ialoveni, Anenii Noi and Causeni districts. 
The springs/fountains with water that has hardness less than $7 \mathrm{me} / \mathrm{dm}^{3}$ and meets the criteria for drinking scope are in total 77 (21\%), most being in Soldanesti (19), Calarasi (13), Criuleni (12 ) and Rezina (11) districts and the least - in Ialoveni, Orhei, Telenesti, Stefan Voda and Anenii Noi. It was found that hardness does not exceed the sanitary acceptable limits for consumption ( $\left.7-10 \mathrm{me} / \mathrm{dm}^{3}\right)$ in water from 129 of springs/fountains, most being in Rezina, Telenesti and Orhei districts. A high content of dissolved salts (mineralization greater than $1000 \mathrm{mg} / \mathrm{dm}^{3}$ ) and hardness exceeding $10 \mathrm{me} / \mathrm{dm}^{3}$ (very hard water) were in 67 sources (the Rezina district there are 19 localities and Ialoveni - 16) (fig. 1).

The main concern is the fact that on average about $25 \%$ of the springs/fountains ( 89 out of 362 ) contain polluted water, the nitrate content exceed the MAC $\left(50 \mathrm{mg} / \mathrm{dm}^{3}\right)$ from 1 to 6 times, most of them being in villages/communes from Rezina (23) Criuleni (17) and Ialoveni (16) districts.

\section{Water type}

According to scientific classification the waters are defined in terms of weight cations and anions present in excess of $20 \%$ of the total chemical equivalents highlight in a litre of water.

Chemical composition of water from investigated springs/fountains shows that in $94 \%$ of cases water after anion is of bicarbonate type, with various modifications $\left(\mathrm{HCO}_{3}-\mathrm{SO}_{4}, \mathrm{HCO}_{3}-\mathrm{Cl},\left(\mathrm{HCO}_{3}-\mathrm{SO}_{4}-\mathrm{Cl}, \mathrm{HCO}-\mathrm{Cl}-\mathrm{SO}\right)\right.$ and only $5.8 \%$ of the waters are sulphate-bicarbonate type with variations $\mathrm{SO}_{4}-\mathrm{HCO}_{3}-\mathrm{Cl}$ and $\mathrm{SO}_{4}-\mathrm{Cl}-\mathrm{HCO}_{3}$ (fig. 2).

Along with increasing of concentration the ratio $\mathrm{SO}_{4}^{2-} / \mathrm{Cl}^{-}$decreases, instead that due to $\mathrm{CaCO}_{3}$ precipitation in conformity with the product solubility (PS) increases the value of ratio $\mathrm{Mg}^{2+} / \mathrm{Ca}^{2+}$ (PS for $\mathrm{CaCO}_{3}$ is equal to $2.884 .10^{-9}$ $-5.368 \cdot 10^{-9}$ ). It was found also the presence of nitrate type in water of 53 springs/fountains (about $15 \%$ ).

Weakly mineralized groundwater's of bicarbonate (anions) and calcium (cations) type gradually move to more mineralized waters as mixed bicarbonate (anion) and sodium or sodium-magnesium mixed (sometimes sodium) - after cations. They are also highly mineralized ground water, bicarbonate- chloride and bicarbonate-sulphate according to the anions and mixed sodium-magnesium and sodium as cations. That hydrochemical diversity is closely linked to changing of the natural conditions (precipitation, evapotranspiration intensity, depth of the groundwater etc.).

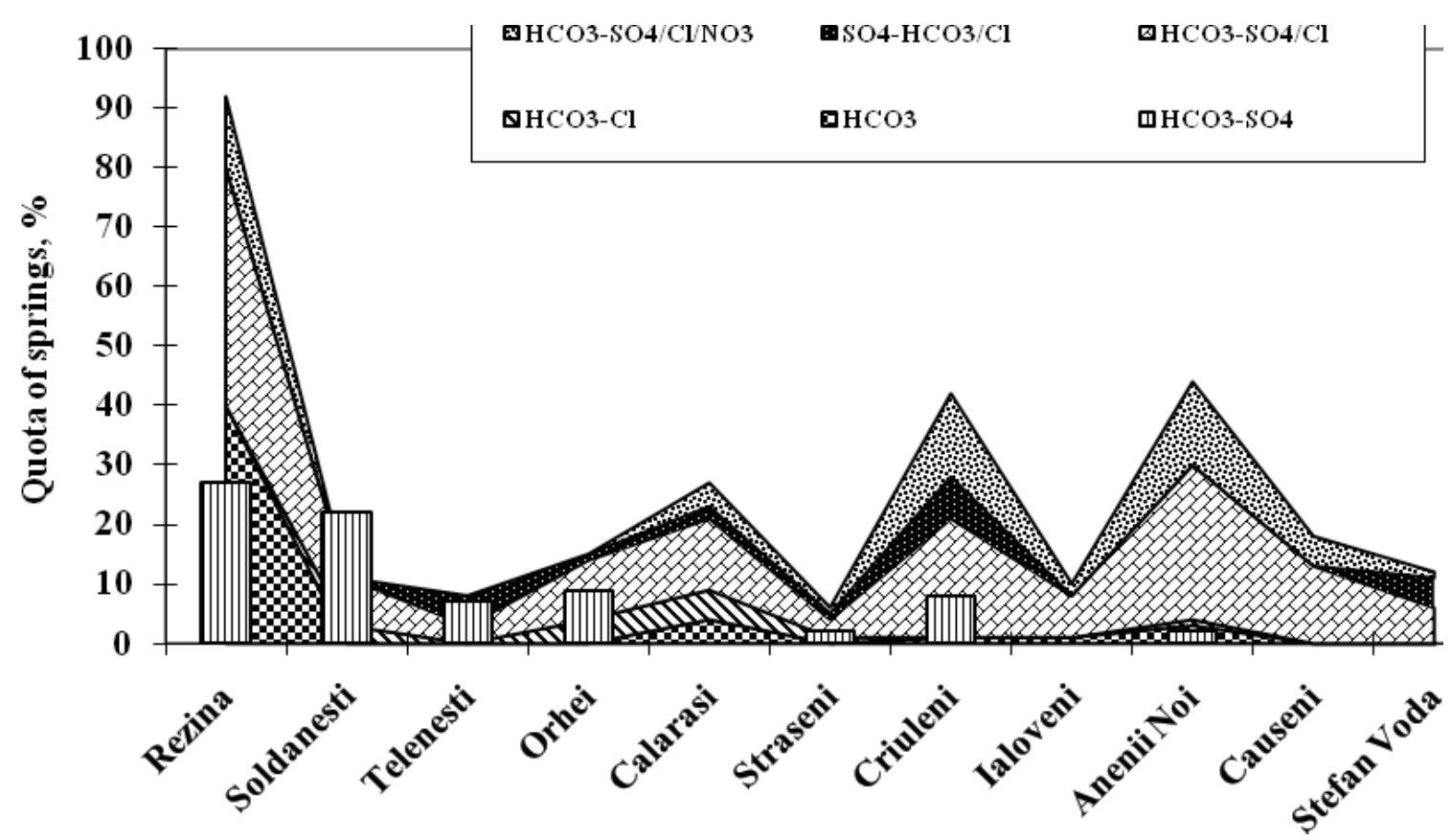

Figure 2. The quota of springs/fountains from investigated villages/communes and water type (according anions).

Depending on the cations content approx. $47 \%$ of the analyzed waters are of calcium type with different secondary cations ( $\mathrm{Ca}-\mathrm{Mg}-\mathrm{Na}, \mathrm{Ca}-\mathrm{Mg}, \mathrm{Ca}-\mathrm{Na}-\mathrm{Mg}, \mathrm{Ca}-\mathrm{Na}$ and $\mathrm{Ca}$ ). Sodium ions prevail in the water composition of $41 \%$ of the springs/fountains, and the magnesium - to $12 \%$ (fig. 3 ). 


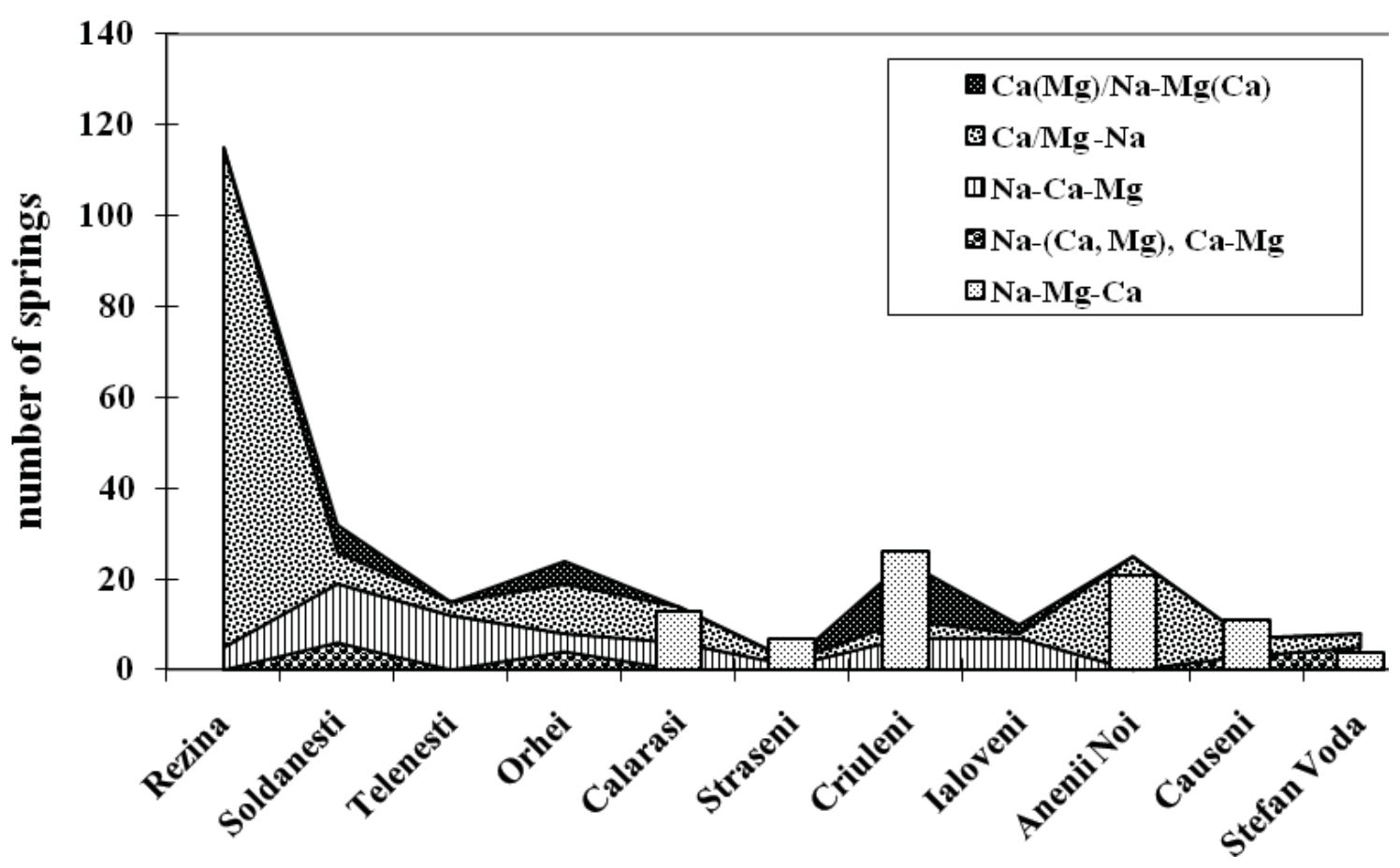

Figure 3. The quota of springs/fountains from investigated villages/communes and water type (according cations).

\section{Correlation between components content in springs/fountains water}

The correlative links between the ions concentration in springs/fountains water were assessed using rank correlation index R of Spearmen with minimum value of 0.05 , which lacks correlation between the content of chemical indicators. By systematizing the mineralization, hardness, content of $\mathrm{Na}^{+}, \mathrm{Ca}^{2+}, \mathrm{Mg}^{2+}, \mathrm{Cl}^{-}, \mathrm{SO}_{4}^{2-}, \mathrm{HCO}_{3}^{-}$and $\mathrm{NO}_{3}^{-}$ions (media per district) of springs/fountains water (basin of the Nistru river) from the centre to the south it was established a positive dynamic with high correlation of mineralization $\left(\mathrm{R}^{2}=0.5171\right), \mathrm{Na}^{+}\left(\mathrm{R}^{2}=0.5614\right), \mathrm{Cl}^{-}\left(\mathrm{R}^{2}=0.5521\right)$ ion concentration and hardness $\left(\mathrm{Ca}^{2+}, \mathrm{Mg}^{2+}\right)\left(\mathrm{R}^{2}=0.45\right)$. The correlation coefficient has medium values for $\mathrm{SO}_{4}{ }^{2-}$-ions $\left(\mathrm{R}^{2}\right.$ $=0.3781)$ and small for $\mathrm{HCO}_{3}^{-}\left(\mathrm{R}^{2}=0.1629\right)$. Practically the correlation for nitrate ions content is absent $\left(\mathrm{R}^{2}=0.0363\right)$ (fig. 4 a, b, c).

Thus to the Southern districts in the water increases the components concentration that arise from contact with the rock, soil solution but water springs/fountains pollution with nitrates persists regardless of studied water source location. It shows a positive correlation between the districts media content of $\mathrm{NO}_{3}^{-}$ions higher than $\mathrm{MAC}$ and water hardness $\left(y=0.72 x+9.2133, R^{2}=0.9959\right)$. Thus, simultaneously with the accumulation of nitrate ions in water increases its hardness. Significantly is the correlation coefficient between the springs quota (\%) water of which is polluted with nitrates, and spontaneous landfills number in districts $\left(\mathrm{R}^{2}=0.7218\right)$ (fig. 5).

The results on nitrate in mineralization in each year of 1-2\% of organic nitrogen [27] in view of the fact that their salts are very soluble in the soil solution and in the form of diffusible ions migrate into the ground water.

\section{Qualifier of springs/fountains water for irrigation use}

The qualification of waters for irrigation purposes was estimated by taking as a basis the coefficient Stebler. By calculating of water irrigation coefficient in the investigated zone, it was found that 213 of sources (about 59\%) have water mark "good" for irrigation, 92 (25\%) - "satisfactory" and 57 of springs and fountains (16\%) have water mark "poor" for irrigation (fig. 6).

The results of the conducted research referred to the groundwater protection and the developed recommendations were elaborated and disseminated in the territory of district authorities and local public administration concerned.

Taken into the fact that Nistru river basin (targeted by research districts) consists small number of Natural Hydrological Monuments protected by the State (14), the research conclusions will be presented to the Ministry of Environment with the scientific argumentation and ecological passports of 6-8 springs/fountains with quality water to be further included in the list of State Protected Natural Areas. 


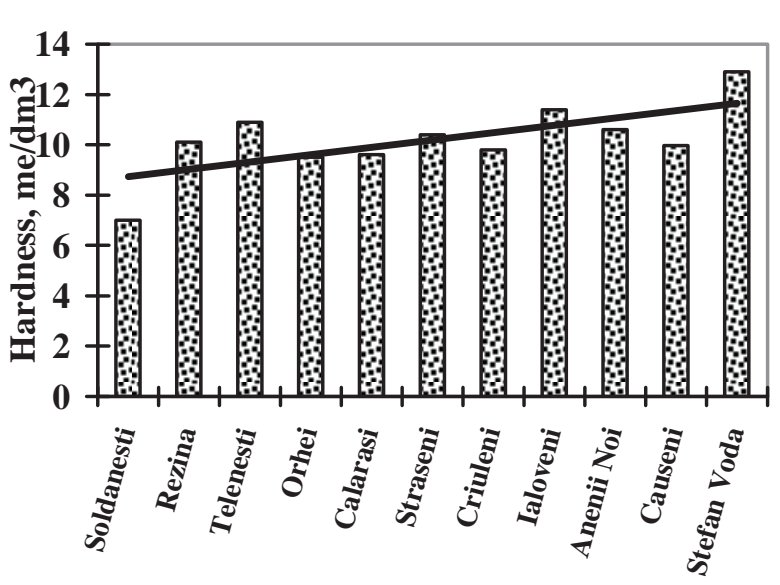

a)
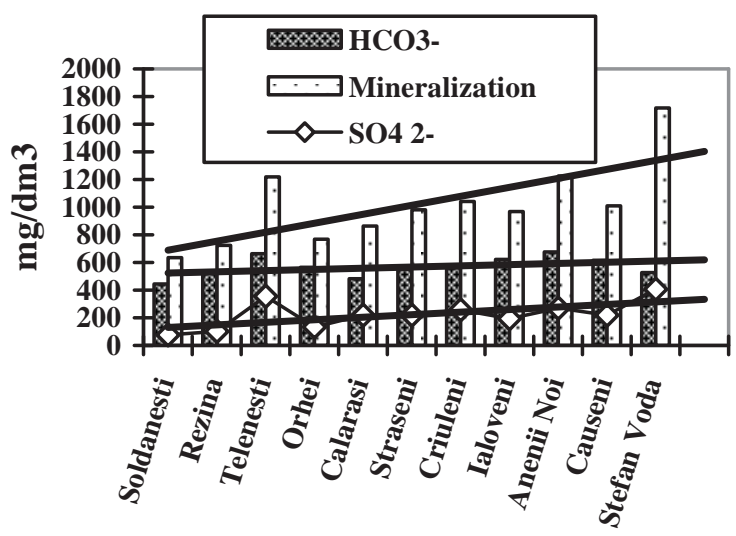

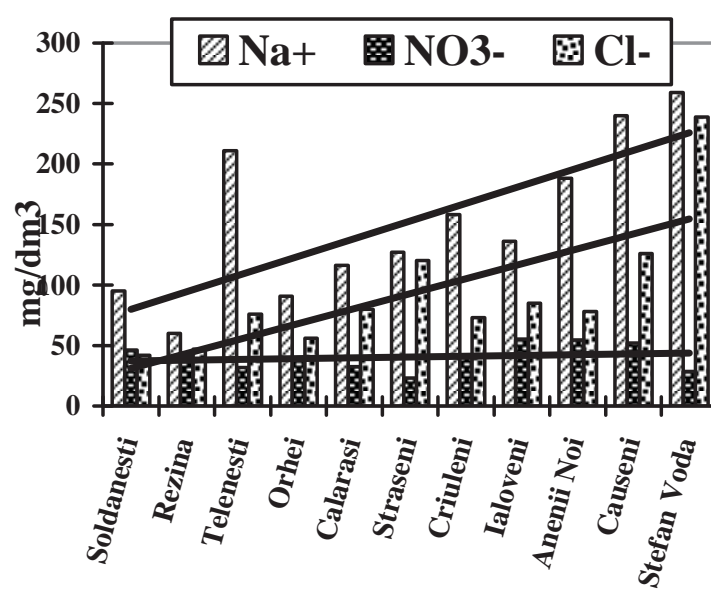

b)
Figure 4. The dynamics (media per district) of hardness (a), $\mathrm{Na}^{+}, \mathrm{Cl}^{-}, \mathrm{NO}_{3}^{-}$ions (b) and mineralization, $\mathrm{SO}_{4}^{2-}, \mathrm{HCO}_{3}^{-}$(c) content in springs/ fountains water (basin of the Nistru river) in direction from centre to the south.

c)

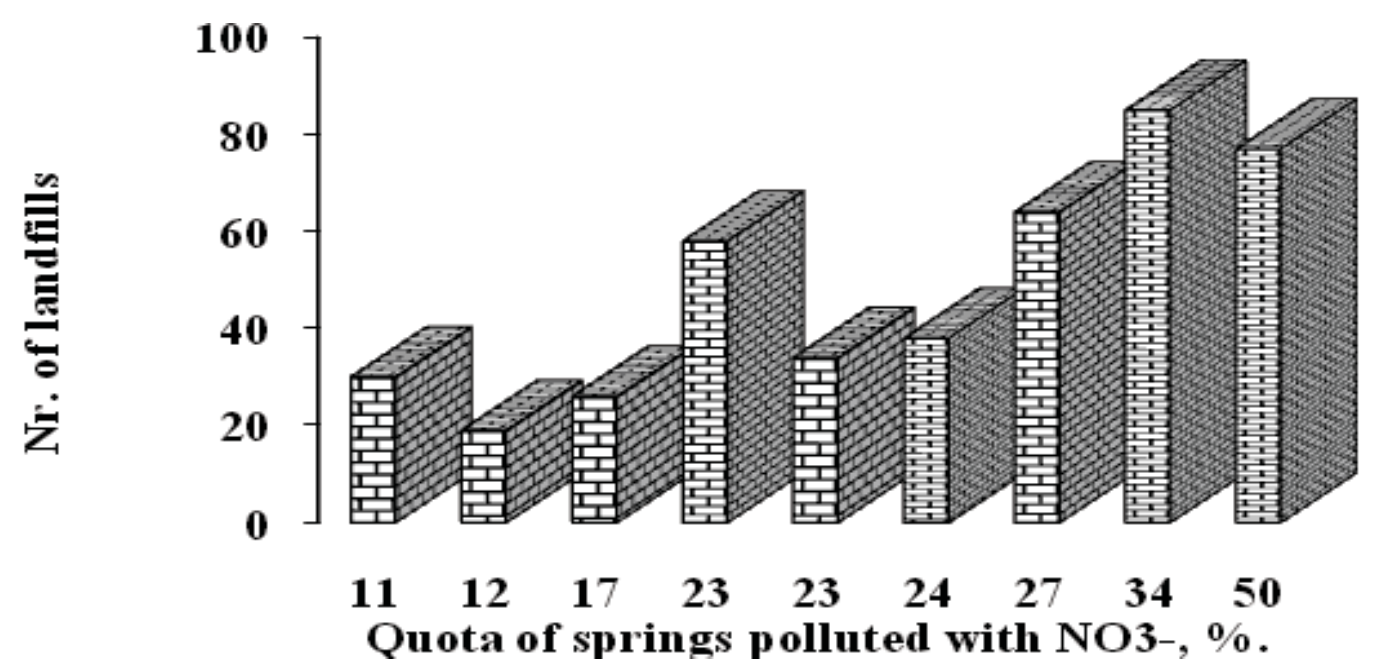

Figure 5. The correlation between the springs quota (\%), water of which is polluted with nitrates, and spontaneous landfills number in districts $\left(R^{2}=0.7218\right)$. 


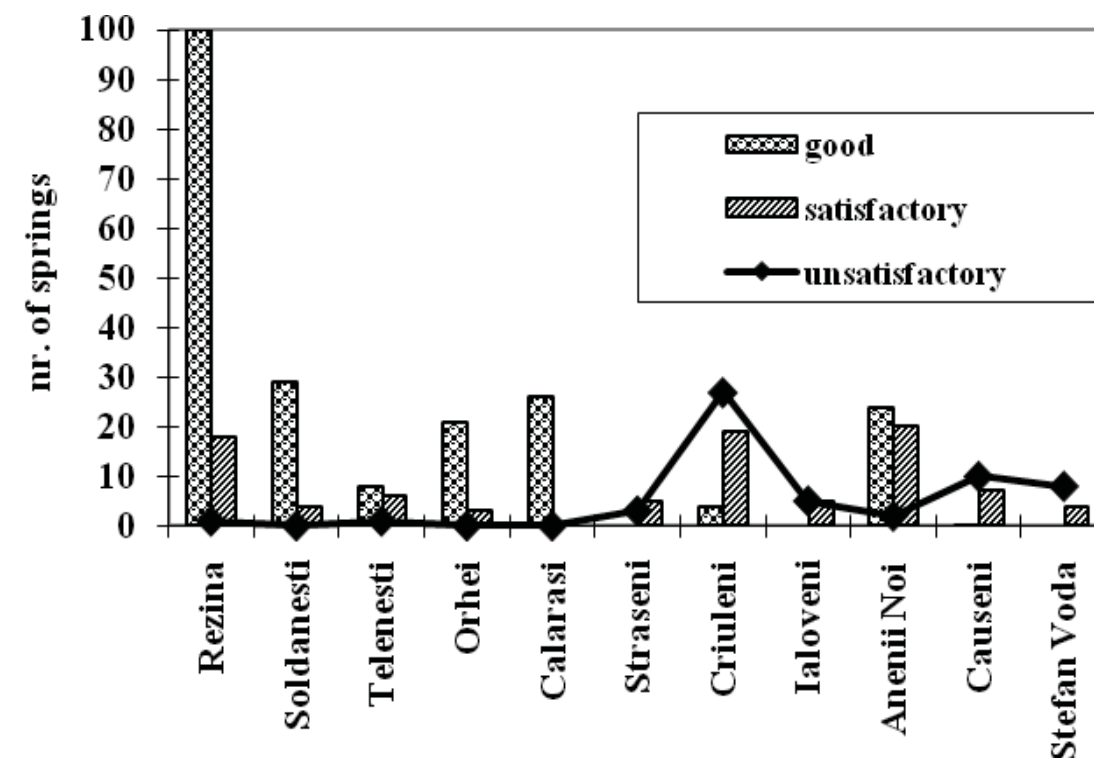

Figure 6. Qualification of waters for consumption in irrigation on districts in the study according to the chemical composition.

\section{Conclusions}

The springs/fountains with water that meets the criteria for potable purposes are in total 77 (21\%); water acceptable from sanitary norms for consumption is present in 129 springs/ fountains. A high content of dissolved salts (mineralization greater than $1000 \mathrm{mg} / \mathrm{dm}^{3}$ ) and hardness exceeding $10 \mathrm{me} / \mathrm{dm}^{3}$ (very hard water) were found in 67 sources (18.5\%) and approx. $25 \%$ of the springs/fountains (89) contain polluted water with nitrate content exceeding MAC with 1 to 6 times.

Chemical composition of water from investigated springs/fountains shows that in about $94 \%$ of cases water after anion is of bicarbonate type, with various modifications $\left(\mathrm{HCO}_{3}-\mathrm{SO}_{4}, \mathrm{HCO}_{3}-\mathrm{Cl},\left(\mathrm{HCO}_{3}-\mathrm{SO}_{4}-\mathrm{Cl}, \mathrm{HCO}_{3}-\mathrm{Cl}-\mathrm{SO}_{4}\right)\right.$ and only $6 \%$ of the waters are sulphate-bicarbonate type with variations $\mathrm{SO}_{4},-\mathrm{HCO}_{3}-\mathrm{Cl}$ and $\mathrm{SO}_{4}-\mathrm{Cl}-\mathrm{HCO}_{3}$.

Nitrate type was found in water of 53 springs/fountains (approx.15\%).

Depending on the cations content approx. $47 \%$ of the analyzed waters are of calcium type with different secondary cations ( $\mathrm{Ca}-\mathrm{Mg}-\mathrm{Na}, \mathrm{Ca}-\mathrm{Mg}, \mathrm{Ca}-\mathrm{Na}-\mathrm{Mg}, \mathrm{Ca}-\mathrm{Na}$ and $\mathrm{Ca}$ ). Sodium ions prevail in water composition of $41 \%$ of the springs/fountains, and the magnesium - to $12 \%$.

The study shows that 213 of springs/fountains (about 59\%) have water mark "good" for irrigation, 92 (25\%) "satisfactory" and 57 (16\%) have water mark "unsatisfactory" for irrigation.

A significant coefficient correlation between the number of polluted water sources with nitrates and the spontaneous dumps in rural districts $\left(\mathrm{R}^{2}=0.7218\right)$ denote that it is necessary to conduct urgent sanitation actions to offset the pollution outbreaks.

\section{Same recommendations for protection of water:}

To prohibit in all areas of domestic and industrial waste storage (liquid and solid) in the zones of water protection, especially for drinking water supply;

To encourage scientific research and education on water protection within the target districts;

To carried out the afforestation and grassing of the area around the water sources;

To organize an ecological reconstruction of water sources, elimination of natural water pollution sources (groundwater and surface water, because the pollutant migrate from one aquifer to another).

\section{References}

[1] Bretotean M. Groundwater, an important natural resource. Bucuresti, 1981, 128 p.

[2] Duca, Gh.; Romanciuc, L. and Porubin, D. Groundwater Resources of Moldova and Transboundary Impact // Transboundary Aquifers in the Eastern Borders of The European Union Regional Cooperation for Effective Management of Water Resources - 2012. - Springer Science + Business Media B.V., pp. 121-127.

[3] Directive 2000/60/EC of the European Parliament and of the Council of 23 October 2000 establishing a framework for Community action in the field of water policy.

[4] Directive 2006/118/EC of the European Parliament and of the Council of 12.12 .2006 on the protection of groundwater against pollution and deterioration. 
[5] Mustea, M.; Boian, I.; Galca, G.; Sandu, M.; Tarita, A.; Zubcov, E.; Sireteanu, D.; Gladchi, V.; Prepelita, A.; Jeleapov, V.; Serenco, L. State of Water Resources and Protection. State of the environment in the Republic of Moldova: The Second Millennium development Goals report Republic of Moldova. - Ch.: "Nova Imprim" SRL, 2011, pp. 75-80.

[6] Ropot, V.; Stratulat, G.; Lupascu, T.; Sandu, M., et al. The problems of water resources quality, use and protection in the Republic of Moldova. Chisinau, Science, 1991, 285 p.

[7] Dumitru, M. Analysis and evaluation of groundwater and deep groundwater resources from Crisul Repede hydrographic basin. Summary of the thesis, Oradea, 2011, 18 p.

[8] Lacatusu, R.; Kovacsovics, B.; Plaxienco, D.; Rasnoveanu, I.; Lungu, M.; Mihalache, D. Load of soils, vegetables and ground waters with fertilizer and pesticides pollutants in the south and east part of Bucharest city // The Environment protection in Agriculture, Bucuresti, 2000, Vol.1., pp. 279-293.

[9] Law nr.272-XIV of 10.02.1999. Official Monitor of the Republic of Moldova, 1999, no. 39-41. Article 1. Basic Terms.

[10] Zavoianu, I. Hidrology. Ed. IV, Bucharest, 2006, 256 p.

[11] Duca, Gh.; Gladchi, V.; Goreaceva, N.; Bunduchi, E.; Borodaev, R.; Lis, A.; Anghel, L.; Surighina, O.; Romanciuc, O. Impact of right tributaries on the Dniester River water quality in the spring of 2009 year. Studia Universitatis. Ser. Science of Nature. 2010, 1, pp. 146-154.

[12] Ropot, V.; Rusu, V.; Sandu, M.; Lozan, R.; et.al. Hydrochemistry of the Dniester river, the problems of its water quality and use. Mater. Resp. Conf. «Ecol. Problems and their solutions.» Chisinau, 1989, pp. 167-171.

[13] Ropot, V.; Sandu, M. Water resources and their quality. National Strategic Action Program in Environment Protection, Chisinau, 1995, pp. 20-25.

[14] Tarita, A.; Sandu, M.; Lozan, R.; Sergentu, E.; Spataru, P.; Mosanu, E.; Goreacioc, T., Jabin V. Water quality of springs and fountains in Nisporeni district// Bulletin of the ASM: Sciences of the Life, 1. pp. 164-169.

[15] Sandu, M.; Sergentu, E.; Tarita, A.; Spataru, P.; Mosanu, E.; Lozan, R. Water quality springs and fountains in the Prut River Basin (Briceni, Edinet, Rişcani districts). The Environment, Chisinau: 2009, nr. 4(46), pp. 36-40.

[16] Mosanu, E.; Tarita, A.; Sergentu, E.; Sandu, M.; Spataru, P.; Goreacioc, T.; Jabin, V. Water quality of springs and fountains from Glodeni and Falesti districts (the Prut River hydrographic Basin). The Environment, Chisinau: 2009, 5(47), pp. 1-4.

[17] Lozan, R.; Tarita, A; Sandu, M.; Mosanu, E.; Sergentu, E. Springs water - an alternative source of water supply for the rural population (Hancesti, Leova, Cahul and Cantemir districts). Bulletin of the ASM. Sciences of the Life. 2010, 1 (310), pp. 165-171.

[18] Sandu, M. The correlation between nitrate and the natural waters macro components content//Bulletin of the ASM: Sciences of the Life. 2004, 3, pp. 116-119.

[19] Overcenco, A.; Mihailescu, C.; Bogdevici, O.; Gilca, G. Wells and springs. Ecological Atlas.Ed. Stiinta. 2008. $208 \mathrm{p}$.

[20] Sandu, M.; Mosanu, E.; Gladchi, V.; Tarita, A.; Duca, Gh.; Spataru, P.; Lupascu, T.; Sergentu, E.; Lozan, R.; Jabin, V.; Turcan, S. Study of springs water quality as sources of potable water and for irrigation in Rezina district. Chem. J. Moldova. 2010, 5 (1), pp. 84-89.

[21] Lozan, R.; Tarita, A.; Sandu, M.; Gladchi, V.; Mosanu, E.; Procopii, D.; Spataru, P.; Jabin, V.; Turcan, S. Spring - indicator of the ecological state of the territory (Orhei, Telenesti and Soldanesti districts). The Environment, Chisinau: 2011, 2 (56), pp.15-20.

[22] Lozan, R.; Tarita, A.; Sandu, M.; Mosanu, E.; Procopii, D.; Gladchi, V. Aspects of springs and fountains water quality parameters in Criuleni and Calarasi districts. International Scientific Conference dedicated to the 65th anniversary of USM, 21-22 September 2011. Abstracts and apers. Natural and exact Sciences, Chisinau, 2011, Vol. II. pp. 70-72.

[23] Sandu, M.; Tarita, A.; Lozan, R.; Mosanu, E.; Spataru, P.; Procopii, D.; Turcan, S.; Jabin, V. Spring - underground aquifer indicator of pollution by nitrates (river Nistru basin). Ch.: The V Intern. Conf.-Symposium Ecological Chemistry 2012, ASM, March 2-3, 2012, pp. 60-61.

[24] Gaidau, A.; Zlotea, A.; Tarita, A.; Lozan, R.; Sandu, M. The springs from river Nistru Basin water sources for drinking and irrigation consume (Stefan Voda district). Ecological Chemistry and chemical risk assessment. Ed. XII-a, 7 December 2012. Ch.: CEP USM, 2012, pp. 33-34.

[25] Sidoren, I.; Turcan, S.; Tarita, A.; Lozan, R.; Sandu, M. The springs from river Nistru Basin -water sources for drinking and irrigation consume (Causeni district). Ecological Chemistry and chemical risk assessment. Ed. XII-a, 7 December 2012. Ch.: CEP USM, 2012, pp. 86-88.

[26] SR EN 25667-2:2002. Water quality - Sampling. Part 2: Guidance on sampling techniques.

[27] SR EN ISO 9963-1. Water quality. Determination of alkalinity. Part 1: Determination of total and permanent alkalinity.

[28] SR ISO 7150-1. Water quality. Determination of ammonia. Part 1: Manual Spectrometric method. 
[29] Standardized methods for studying water quality. Methods for analysis of water, Nauka, Moscow, 1983,108 p.

[30] Novikov, I. V.; Lastocichina, S. O.; Boldina, Z. I. Methods for determining of harmful substances. Moscow: Medicine. 1981, 376 p.

[31] Nickanorov, A.M.; Posohov, E.V. Hydrochemistry. - L., Hydrometeoizdat. 1985. 252 p.

[32] The Government Decision of the Republic of Moldova Nr. 934 in 15.08.2007. The Official Monitor of the Republic of Moldova Nr. 131-135 in 24.08.2007. Art. nr. 970. Annex nr.2. Health norms for drinking water quality.

[33] Anscombe, F. J. Graphs in Statistical Analysis. American Statistician, 1973, 27, pp. 17-21.

[34] Hopkins, W. G. (2000). A new view of statistics. Internet Society for Sport Science: http://www.sportsci.org/ resource/stats/.

[35] Plotnikova N.M. Hydrogeology of USSR, T. VII. Republic of Moldova. "Nedra", 1966, 174 p.

[36] Prisiajniuk, A.C. Review of underground waters of the Republic of Moldova, T. I. Hydrological Report. M. 1972, $38 \mathrm{p}$. 